Review Article

\title{
Climate Change and Mango Production
}

\author{
Shuvadeep Halder* and Md. Abu Hasan
}

Department of Fruit Science, Faculty of Horticulture, Bidhan Chandra Krishi Viswavidyalaya, Mohanpur, Nadia, 741252, W.B.

\begin{abstract}
The increasing concentration level of atmospheric $\mathrm{CO}_{2}$, which is a major factor of climate change, has to be considered for the consequences of climate change on agriculture because $\mathrm{CO}_{2}$ is involved in the key processes for plants, such as photosynthesis. Irregular cropping is the biggest problem in mango production. Inconsistent run of cool nights and relatively warm winter has adversely affected flowering in mango. Increases in extreme mean temperatures are already affecting mango production. So, rapid climate change should be a great concern irrespective of mango growers, scientists and buyers. The large diversity in genetic resources of mango is a boon for selection and breeding programs to face climatic changes. To fight against this climate change some strategies could be taken like substitution and complementation of low temperature by using growth retardant (PB Z) along with imposition of moisture stress $(-75 \mathrm{kpa}$ or even less) for about 4 months prior to flowering, post-harvest thinning of large branches of vigorous and late varieties grown in heavy soils to encourage soil moisture loss during winter months, digging trenches along the drip line for better drainage during monsoon and ensuring moisture stress condition during winter months, encouraging new mango plantation in light and sandy loam soils which has the capacity to loss moisture quickly, shoot pruning after harvest (impracticable for tall growing trees) to encourage more new shoots which become mature (8-9 months) at the time of flowering followed by nutrients and irrigation.
\end{abstract}

\section{Introduction}

Climate change will be a tremendous threat not only for mango production but also for the whole agriculture in the upcoming century. The increasing concentration level of atmospheric $\mathrm{CO}_{2}$, which is a major factor of climate change, has to be considered for the consequences of climate change on agriculture because $\mathrm{CO}_{2}$ is involved in the key processes for plants, such as photosynthesis. Mango, a seasonal fruit, is one of the most widely cultivated and popular fruits in the tropical and the subtropical climate for its economic and nutritional values. in so many countries including Cambodia, Pakistan, China, Philippines etc.

\section{Effect on Photosynthesis}

Temperature, light and $\mathrm{CO}_{2}$ concentration are the primary components which are important for photosynthesis. So, an expected increase of these components would have a positive effect on photosynthesis. But rising of temperature and $\mathrm{CO}_{2}$ concentration have counterbalanced effects because they increase photosynthetic assimilation as well as respiratory losses. Higher temperatures $\left(>45^{\circ} \mathrm{C}\right)$ or higher levels of light intensity are detrimental to the photosynthesis process. Drought and vapour pressure deficit (VPD) also have a negative effect on photosynthesis because of the rapid stomatal closure. Flooding or drought both has probably a negative effect on the photosynthesis process of mango. Flooding leads to a rapid decrease of transpiration, stomatal conductance and maximal photosynthetic assimilation.

\section{Effect on Vegetative growth}

Vegetative growth of mango is also influenced by weather conditions. Soil temperature is highly influenced by ambient temperature and it has a strong effect on the vegetative and reproductive growth of mango [1]. In another 
experiment mean leaf size of trees grown at $30 / 25^{\circ \mathrm{C}}$ (day/night temperature) was $300 \%$ greater than that of trees growing at $20 / 15^{\circ \mathrm{C}}$ [2]. But, a group of scientists did not observe any significant effect of temperature on leaf size for leaves which developed in the mean daily temperature range of $20-28^{\circ \mathrm{C}}$ [3]. Drought and flooding have both negative effects on the vegetative development of mango trees as they reduce tree growth.

\section{Effect on Flowering and Fruit Set}

The floral induction of mango is mainly induced by cool temperatures. So, higher temperature during floral induction should have a negative effect. But cooler temperature during flowering followed by higher temperatures would have a positive effect on pollen viability and fruit set. Among the factors responsible for flowering in mango, suitable environmental conditions namely low night temperature $\left(<12^{0} \mathrm{c}\right)$ and soil moisture stress $(-75 \mathrm{kpa}$ or even less) before flowering trigger in mango. However, moisture stress can supplement the low temperature requirement to a great extent depending on varieties and induce flowering in mango. Mango grown in light soils (which have the capacity to less moisture quickly) produced better flowering in spite of experiencing warm winter prior to flowering. Flower in Himsagar (Khirsapati) had been worst affected during the years even in more moisture stressed situation grown in light soils. Intensification of flower induction under such prevailing warm winter could be supplemented by using growth retardants along with imposition of moisture stress prior to flowering (4 months dry period). In general, the erratic/low/no flowering in late and vigorous varieties like Aswina, Fazli etc. grown in heavy soils were because of low soil moisture stress due to delaying monsoon upto first fortnight of October as well as lack of cool winters. If the situation (global warming and climatic change) prevails in the coming years, the mango production in the state will be at stake. Higher temperature also has a negative effect on inflorescence size and on the number of flowers per inflorescence respectively [3], [4]. A group $\mathrm{p}$ of scientists observed better vegetative growth at $30^{\circ \mathrm{C}}$ day and $25^{\circ \mathrm{C}}$ night temperatures and floral induction at $15^{\circ \mathrm{C}}$ day and $10^{\circ \mathrm{C}}$ night temperatures in mono and polyembryonic cultivars [5]. Light intensity has a positive effect on mango flowering. Unfavourable environmental conditions viz., rain, humidity, temperature, light, wind, drought, water logging, etc have detrimental effects on mango flowering because it is the most sensitive stage to climate. Fruit set and retention is negatively influenced by drought and higher vapour pressure deficit (VPD). Drought could indirectly help in floral induction by promoting early growth cessation and vegetative rest which are very important for floral induction.

\section{Effect on Fruit Growth and Quality}

Rising temperatures would have a positive effect on mango fruit growth. The estimated duration of mango fruit development in Australia decreased by $12-16$ days (7-8\%) as a consequence of the $1.5^{\circ \mathrm{C}}$ increase of winter temperatures over the last 45 years [6]. Higher temperature may be beneficial to fruit quality because of stressinduced by higher temperature helps to synthesis of secondary compounds which are involve to increase some nutritional value. However high temperature also induces physiological changes within the mango fruit. Spongy tissue, a physiological disorder in Alphonso mango, is induced by higher temperatures within the fruits, leading to tissue breakdown. In an experiment higher light intensity enhances skin colour for coloured cultivars [7]. Excessive light could also have a positive effect on fruit size by enhancing photosynthesis [8]. AS higher $\mathrm{CO}_{2}$ concentration also enhances photosynthesis could have a positive effect on fruit quality by accumulating larger fruit dry mass. Drought has both positive and negative effect on fruit quality and well-known in non-irrigated orchards. Drought reduces fruit size [9] but increases fruit quality by increasing the dry matter content and sugar concentration [10].

\section{Conclusions}

Mango has a large ecological adaptation to stressful environments and has physiological mechanisms to fight against these environments. The large diversity in genetic resources is a boon for selection and breeding programs to face climatic changes. But global climate changes, high temperature and drought will tolerate up to a certain point with the genetic diversity of mango. So, rapid climate change should be a great concern irrespective of mango growers, scientists and buyers. To help, protect and overcome mango industry in the scenario of climate change some strategies could be taken like substitution and complementation of low temperature by using growth retardant (PB Z) along with imposition of moisture stress (-75 kpa or even less) for about 4 months prior to flowering, post-harvest thinning of large branches of vigorous and late varieties grown in heavy soils to encourage soil moisture loss during winter months, digging trenches along the drip line for better drainage during monsoon and ensuring moisture stress condition during winter months, encouraging new mango plantation in light and sandy loam soils which has the capacity to loss moisture quickly, shoot pruning after harvest (impracticable for tall growing trees) to encourage more new shoots which become mature (8-9 months) at the time of flowering followed by nutrients and irrigation. Beside 
this we should avoid new plantation in heavy soil, post monsoon fertilization, irrigation during and ploughing orchard floor during winter months.

\section{References}

[1] Yusof, I.M., Buchanan, D.W. and Gerber, J.F. 1969. The response of avocado and mango to soil temperature. Journal of the American Society for Horticultural Science. 94: 619-612.

[2] Whiley, A.W., Rasmussen, T.S., Saranah, J.B. and Wolstenholme, B.N. 1989. Effect of temperature on growth, dry matter production and starch accumulation in ten mango (Mangifera indica L.) cultivars. J. Hort. Science 64:753-765.

[3] Dambreville, A., Normand, F. and Lauri, P-E. 2013. Plant growth co-ordination in natura: a unique temperature-controlled law among vegetative and reproductive organs in mango. Functional Plant Biology 40:280-291.

[4] Sukhvibul, N., Whiley, A.W., Smith, M.K., Hetherington, S.E. and Vithanage, V. 1999. Effect of temperature on inflorescence development and sex expression of mono- and poly-embryonic mango (Mangifera indica L.) cultivars. J. Hort. Science \& Biotechn. 74:64-68.

[5] Whiley, A.W., Rasmussen, T.S, Wolstenholme, B.N., Saranah, J.B. and Cull, B.W. 1991. Interpretation of growth responses of some mango cultivars grown under controlled temperature. Acta Horticulture. 291: 22-31.

[6] Olesen, T. 2011. Late 20th century warming in a coastal horticultural region and its effects on tree phenology. New Zealand J. Crop Hort. Science 39(2):119-129.

[7] Léchaudel, M., Lopez-Lauri, F., Vidal, V., Sallanon, H. and Joas, J. 2013. Response of the physiological parameters of mango fruit (transpiration, water relations and antioxidant system) to its light and temperature environment. J. Plant Physiol. 170:567-578.

[8] Urban, L., Le Roux, X., Sinoquet, H., Jaffuel, S. and Jannoyer, M. 2003. A biochemical model of photosynthesis for mango leaves: evidence for an effect of the fruit on photosynthetic capacity of nearby leaves. Tree Physiol. 23:289-300.

[9] Spreer, W., Ongprasert, S., Hegele, M., Wünsche, J.N. and Müller, J. 2009. Yield and fruit development in mango (Mangifera indica L. cv. Chok Anan) under different irrigation regimes. Agric. Water Manage. 96:574584.

[10] Léchaudel, M., Joas, J., Caro, Y., Génard, M. and Jannoyer, M. 2005b. Leaf: fruit ratio and irrigation supply affect seasonal changes in minerals, organic acids and sugars of mango fruit. Journal of the Science of Food and Agriculture 85(2):251-260.

(C) 2020, by the Authors. The articles published from this journal are distributed to the public under "Creative Commons Attribution License" (http://creative commons.org/licenses/by/3.0/). Therefore, upon proper citation of the original work, all the articles can be used without any restriction or can be distributed in any medium in any form. For more information please visit www.chesci.com.
Publication History

Received $\quad 12.12 .2019$

Revised 10.01.2019

Accepted $\quad 15.01 .2020$

Online $\quad 15.01 .2020$ 